University of Nebraska - Lincoln

DigitalCommons@University of Nebraska - Lincoln

U.S. National Park Service Publications and

Papers

National Park Service

$11-9-2019$

\title{
Satellite-based decadal change assessments of pan-Arctic environments
}

Liza K. Jenkins

Michigan Technological University, Iliverse@mtu.edu

Tom Barry

University of Iceland, tom@caff.is

Karl R. Bosse

Michigan Technological University, krbosse@mtu.edu

William S. Currie

The University Of Michigan, wcurrie@umich.edu

Tom Christensen

Aarhus University, toch@bios.au.dk

Follow this and additional works at: https://digitalcommons.unl.edu/natlpark

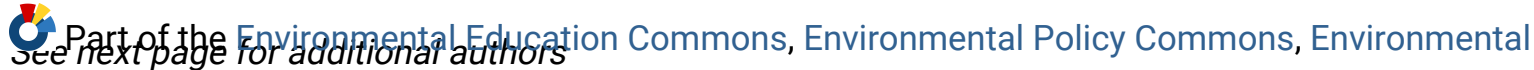
Studies Commons, Fire Science and Firefighting Commons, Leisure Studies Commons, Natural Resource

Economics Commons, Natural Resources Management and Policy Commons, Nature and Society

Relations Commons, Other Environmental Sciences Commons, Physical and Environmental Geography

Commons, Public Administration Commons, and the Recreation, Parks and Tourism Administration

Commons

Jenkins, Liza K.; Barry, Tom; Bosse, Karl R.; Currie, William S.; Christensen, Tom; Longan, Sara; Shuchman, Robert A.; Tanzer, Danielle; and Taylor, Jason J., "Satellite-based decadal change assessments of panArctic environments" (2019). U.S. National Park Service Publications and Papers. 203.

https://digitalcommons.unl.edu/natlpark/203

This Article is brought to you for free and open access by the National Park Service at DigitalCommons@University of Nebraska - Lincoln. It has been accepted for inclusion in U.S. National Park Service Publications and Papers by an authorized administrator of DigitalCommons@University of Nebraska - Lincoln. 


\section{Authors}

Liza K. Jenkins, Tom Barry, Karl R. Bosse, William S. Currie, Tom Christensen, Sara Longan, Robert A. Shuchman, Danielle Tanzer, and Jason J. Taylor 


\title{
Satellite-based decadal change assessments of pan-Arctic environments
}

\author{
Liza K. Jenkins (1), Tom Barry, Karl R. Bosse, William S. Currie, \\ Tom Christensen, Sara Longan, Robert A. Shuchman, Danielle Tanzer, \\ Jason J. Taylor
}

Received: 14 November 2018/Revised: 20 March 2019/Accepted: 22 May 2019/Published online: 4 November 2019

\begin{abstract}
Remote sensing can advance the work of the Circumpolar Biodiversity Monitoring Program through monitoring of satellite-derived terrestrial and marine physical and ecological variables. Standardized data facilitate an unbiased comparison across variables and environments. Using MODIS standard products of land surface temperature, percent snow covered area, NDVI, EVI, phenology, burned area, marine chlorophyll, CDOM, sea surface temperature, and marine primary productivity, significant trends were observed in almost all variables between 2000 and 2017. Analysis of seasonal data revealed significant breakpoints in temporal trends. Within the terrestrial environment, data showed significant increasing trends in land surface temperature and NDVI. In the marine environment, significant increasing trends were detected in primary productivity. Significantly earlier onset of green up date was observed in bioclimate subzones $\mathrm{C} \& \mathrm{E}$ and longer end of growing season in B\&E. Terrestrial and marine parameters showed similar rates of change with unidirectional change in terrestrial and significant directional and magnitude shifts in marine.
\end{abstract}

Keywords Arctic - MODIS - Remote sensing - Satellite · Time series

\section{INTRODUCTION}

Climate change models consistently predict the greatest expected warming to occur in high northern latitudes. Similarly, reports from the Intergovernmental Panel on

Electronic supplementary material The online version of this article (https://doi.org/10.1007/s13280-019-01249-z) contains supplementary material, which is available to authorized users.
Climate Change (IPCC) convey the expectation that the Arctic region will warm 2-3 times more than the global mean (IPCC 2018). Models predict that the Arctic will warm $4.3-7.6^{\circ} \mathrm{C}$ by 2100 compared to the predicted global mean warming of $1.5-2.7^{\circ} \mathrm{C}$ (IPCC 2018). Proxy Arctic temperature records from the past 2000 years above $60^{\circ} \mathrm{N}$ latitude show the last half-century being the warmest of the past two millennia, with the previous, long-term Arctic cooling trend being reversed during the 20th century (Kaufman et al. 2009).

A warmer Arctic is expected to have many physical and ecological consequences, all operating within a set of complex feedback mechanisms. Reduction in sea ice and permafrost, changes to surface hydrology, as well as shifts in vegetation zones, biomass, and productivity are among some of the expected primary consequences of a warmer Arctic. Secondary consequences include severe disruptions to biodiversity with anthropogenically driven climate change being the most serious threat to biodiversity in the Arctic (Meltofte 2013).

As the Arctic continues to experience a period of intense and accelerating change, it has become increasingly important to expand access to information on the status and trends of Arctic biodiversity. The Arctic Council is the leading intergovernmental forum promoting cooperation, coordination, and interaction among the Arctic States, Arctic Indigenous Peoples (represented by the Permanent Participants ${ }^{1}$ ) and other Arctic inhabitants on issues common within the Arctic, in particular, on issues of sustainable development and environmental protection in the

\footnotetext{
$\overline{1}$ The Arctic Council Permanent Participants are Aleut International Association; Arctic Athabaskan Council; Gwich'in International; Inuit Circumpolar Council; Saami Council; Russian Association of indigenous Peoples of the North.
} 
Arctic. The Arctic Council has recommended that longterm monitoring efforts and inventories should be increased and focused to address key gaps in knowledge to better facilitate the development and implementation of conservation and management strategies (ACIA 2004; Meltofte 2013) as well as take action on monitoring advice from what is presently known about Arctic ecosystems.

The Circumpolar Biodiversity Monitoring Program (CBMP) is the cornerstone program of the Conservation of Arctic Flora and Fauna (CAFF), the Arctic Council's biodiversity working group. The CBMP aims to be multiknowledge based, utilizing science through bringing together an international network of scientists, government institutions, Indigenous organizations, and conservation groups working to harmonize and integrate efforts to monitor the Arctic's living resources. Its goal is to facilitate understanding, and more rapid detection and communication of significant biodiversity-related trends and pressures affecting the circumpolar world, while also establishing international linkages to global biodiversity initiatives.

Implementing the CBMP across marine, terrestrial, freshwater, and coastal ecosystems has largely focused on evaluation of in situ data collected across a myriad focal ecosystem components (FECs). The CBMP has identified key elements, called FECs, of Arctic marine, freshwater, terrestrial and coastal ecosystems. Changes in FEC status likely indicate changes in the overall environment and are therefore monitored. Field data collection in the Arctic is logistically and financially challenging and these data remain sparse and disparate, as described in the first of the CBMP State of the Arctic Biodiversity Report (CAFF 2017) and documented throughout this special issue. Recognizing the challenges associated with field data collection in the Arctic and the need for a more comprehensive understanding of change across the Arctic, CAFF initiated the Land Cover Change (LCC) Initiative to evaluate remote sensing for use in Arctic biodiversity monitoring and assessment activities. The work presented here is the result of the CAFF Land Cover Change Initiative.

Climate warming has not been uniform across the panArctic region (Hansen et al. 1999) and responses to warming are expected to similarly exhibit spatial variability (Stow et al. 2004). Large-scale synoptic monitoring tools are needed to assess baseline conditions and detect change and to conduct these analyses across a range of spatial and temporal scales. Remote sensing has the ability to provide these tools as data are available at a variety of spatial, temporal, and radiometric scales.

Several satellites have been designed specifically to provide datasets for ecosystem monitoring at a global scale. Historically the main systems used in studies across the pan-Arctic have included AVHRR (1978-present) and MODIS (1999-present). Studies using AVHRR have been limited by spatial resolution with one pixel covering approximately $1 \mathrm{~km}^{2}$ of land. With the launch of two MODIS satellites in the early 2000s, data are available at a much higher spatial resolution (up to $250 \mathrm{~m}$ ), while also matching AVHRR's almost-daily global cover and exceeding its spectral resolution. MODIS provides images over a given pixel of land just as often as AVHRR, but in much finer detail and with measurements in a greater number of wavelengths using detectors that were specifically designed for measurements of ecosystem dynamics. The European Space Agency's (ESA) Sentinel program, with the first satellite launched in 2014 , continues the path of technological innovation in the field of remote sensing and provides robust earth observation data through a family of missions with each mission based on a constellation of two satellites.

Despite many technological advances in satellite systems, the Arctic presents many challenges to remote sensing-based studies due to persistent cloud cover and haze, snow cover, limited solar illumination, and changing solar zenith angles. Remote sensing scientists have worked to overcome these challenges by identifying systematic bias and developing data processing algorithms to account for these effects. Most notably, cloud cover has been shown to bias land surface temperature (Westermann et al. 2011) and NDVI (Karami et al. 2017). Solutions typically employ mathematics to smooth and remove cloud-induced noise. Other solutions include fitting a model to the data that mimics expected behavior, such as using a sinusoidal model to reproduce seasonal variations (Hachem et al. 2009), or to gap fill cloud-contaminated satellite data using estimates from empirical relationships.

Remote sensing data have frequently been used for specific disciplinary studies at focused locations across the Arctic. Fewer large-scale studies at the landscape or panArctic scale have been conducted, but these studies do indicate strong signals of ecosystem change in the terrestrial environment, especially related to vegetation greening (Jia et al. 2003; Goetz et al. 2005; Bhatt et al. 2010, 2013; Reichle et al. 2018), an increase in shrub cover and decrease in freshwater surface area (Stow et al. 2004). PanArctic studies of marine environments also indicate significant change, including a decline in Arctic sea ice extent (Stroeve and Notz 2018; Parkinson et al. 1999; Comiso et al. 2008; Frey et al. 2015) and increasing trends in Arctic marine primary productivity (Arrigo et al. 2008; Hill et al. 2012).

Remote sensing determination of vegetation "greening" is often based on the normalized difference vegetation index (NDVI). The NDVI is a remote sensing-based quantification using visible and near-infrared light reflected by vegetation. Many studies of NDVI show a strong correlation to in situ percent vegetation cover measurements in 
the Arctic (Hope et al. 1993; Stow et al. 1993; Laidler et al. 2007). Using NDVI, recent research points to spatial heterogeneity with an ongoing general greening trend starting in the 1980s (Jia et al. 2003; Goetz et al. 2005; Bhatt et al. 2010, 2013; Reichle et al. 2018). NDVI has also been linked to measurements of the Arctic growing season (McDonald et al. 2004; Park et al. 2016). The NDVI has been the standard remote sensing-derived vegetation index for decades, being used in a wide variety of vegetation studies globally. With the launch of MODIS, the enhanced vegetation index (EVI) was developed to reduce background and atmospheric noise and to eliminate saturation in high-biomass regions (Huete et al. 1999). NDVI are EVI are computed similarly and exploit the same relationship between red and NIR wavelengths, with EVI additionally using data from the blue band and some aerosol resistance terms. In the presence of snow, NDVI decreases, while EVI increases (Huete et al. 2002), which is an important distinction to consider in remote sensing-based studies across the pan-Arctic.

Previous work on detecting trends in Arctic vegetation phenology from remote sensing have indicated longer growing seasons, primarily due to an earlier start of growing season by 4.7 days per decade and a delayed end of growing season by 1.6 days per decade over the observation period of 2000-2010 in high northern latitudes (Zeng et al. 2011). Estimates in phenology shifts were shown to differ in North America and Eurasia with North America having a significantly earlier start of season and a slightly later end of season (Zeng et al. 2011). North America also appears to be "greening" to a greater extent than Eurasia (Dye and Tucker 2003; Bunn et al. 2007; Bhatt et al. 2010).

Five Arctic tundra bioclimatic zones have been identified and mapped in the Circumpolar Arctic Vegetation Map (CAVM Team 2003). These delineations are described as subzones A-E ranging from North to South with subzone A being the coldest and subzone $\mathrm{E}$ the warmest. These bioclimatic zones have been used to describe Arctic vegetation trends in many scientific studies (Jia et al. 2009; Epstein et al. 2012; Reichle et al. 2018) and represent an ecologically meaningful way to divide the Arctic for trend reporting.

In addition to studies on vegetation, satellite remote sensing data have shown a decline in freshwater surface area attributed to degradation of permafrost in the Arctic since the 1950s (Smith et al. 2005; Riordan et al. 2006; Carroll et al. 2011). In Siberia, there is a decreasing trend in Arctic lake abundance since the early 1970s (Smith et al. 2005). In Arctic Alaska, remote sensing data validated with field surveys have also shown a decrease in a majority of pond surface area from 1950 to 2000 (Stow et al. 2004). From 2003 to 2010, satellite microwave remote sensing data also show seasonal and annual variability in surface inundation in Arctic Alaska with wetting trends within continuous and discontinuous permafrost zones and drying trends in sporadic and isolated permafrost zones (Watts et al. 2012).

The objective of this paper is to demonstrate the applicability of remote sensing as a multi-parameter monitoring tool for implementation within the CBMP. Data from this study will begin a formation of baselines and provide a pan-Arctic understanding of the status of spatial and temporal trends across multiple parameters simultaneously. The goal is to measure magnitudes and rates of change and to develop a methodology for synoptic monitoring in the pan-Arctic going forward.

\section{MATERIALS AND METHODS}

Remote sensing data used in this study are from the MODIS (Moderate Resolution Imaging Spectroradiometer) instrument aboard the Terra and Aqua satellites. MODIS data are acquired every 1 to 2 days worldwide in 36 spectral bands, with more frequent coverage in the Arctic due to the sun-synchronous satellite orbit providing up to 4 daily overpasses. Aside from raw radiometric data, MODIS data are available in a variety of derived products that span many disciplines and applications. MODIS standard data products are used in this study to provide a common data input across all investigated parameters. The specific remote sensing products used in this study are detailed with metadata in Table 1. Time periods of observation range from 14 to 18 years. MODIS standard data products are used for all study parameters with the exception of sea ice extent. For this parameter, a combined passive microwave satellite product (Stroeve and Meier 2017) from SMMR and SSM/I-SSMIS are used.

Systematic biases and known areas of concern for each MODIS data product are documented in the Algorithm Theoretical Basis Documents (ATBS's) and throughout the scientific literature. Data quality flags are developed based upon these concerns, but treatment varies significantly product-to-product. Some products have quality flags with limited usefulness. For example, the snow covered area product used in this analysis (MOD10CM) only reports pixels as having "good" or "other" quality. In order to get more detailed quality information, one must look at the quality flags in the lower level data that feed into the monthly aggregated product used in this analysis (Riggs and Hall 2016). There are other known limitations of the products used here. These issues include difficulty distinguishing snow and clouds in the snow cover product (Hall and Riggs 2007); lower quality phenology detections due to high solar zenith angles, snow, and cloud cover; and land 
Table 1 A set of remote sensing-based physical and ecological parameters in both the marine and terrestrial pan-Arctic environments were analyzed in this study. This table outlines the parameters and metadata, including the spatial and temporal selection

\begin{tabular}{|c|c|c|c|c|c|}
\hline $\begin{array}{l}\text { Physical and ecological } \\
\text { parameters }\end{array}$ & $\begin{array}{l}\text { Satellite platform; product name; } \\
\text { version number }\end{array}$ & $\begin{array}{l}\text { Temporal } \\
\text { selection available }\end{array}$ & $\begin{array}{l}\text { Temporal } \\
\text { selection used }\end{array}$ & $\begin{array}{l}\text { Spatial } \\
\text { resolution }\end{array}$ & Data source \\
\hline $\begin{array}{l}\text { Land Surface Temperature } \\
\text { (LST), Day }\end{array}$ & MODIS Terra; MOD11C3; 6 & Monthly, 2000-2017 & $\begin{array}{c}\text { 2001-2017, } \\
\text { Jan-Dec }\end{array}$ & $0.05^{\circ}(\sim 5600 \mathrm{~m})$ & LPDAAC \\
\hline $\begin{array}{l}\text { Percent snow covered } \\
\text { area (snow) }\end{array}$ & MODIS Terra; MOD10CM; 6 & Monthly, 2000-2017 & $\begin{array}{r}\text { 2003-2017, } \\
\text { Mar-Oct }\end{array}$ & $0.05^{\circ}(\sim 5600 \mathrm{~m})$ & NSIDC \\
\hline $\begin{array}{l}\text { Normalized difference } \\
\text { vegetation index (NDVI) }\end{array}$ & MODIS Terra; MOD13C1; 6 & 16-day; 2000-2017 & $\begin{array}{r}\text { 2001-2017, } \\
\text { May-Sep }\end{array}$ & $0.05^{\circ}(\sim 5600 \mathrm{~m})$ & LPDAAC \\
\hline $\begin{array}{l}\text { Enhanced vegetation } \\
\text { index (EVI) }\end{array}$ & MODIS Terra; MOD13C1; 6 & 16-day; 2000-2017 & $\begin{array}{r}\text { 2001-2017, } \\
\text { May-Sep }\end{array}$ & $0.05^{\circ}(\sim 5600 \mathrm{~m})$ & LPDAAC \\
\hline Green up date & $\begin{array}{l}\text { MODIS Aqua, Terra; } \\
\text { MCD12Q2; } 5\end{array}$ & Yearly, 2001-2014 & 2001-2014 & $500 \mathrm{~m}$ & LPDAAC \\
\hline Senescence date & $\begin{array}{l}\text { MODIS Aqua, Terra; } \\
\text { MCD12Q2; } 5\end{array}$ & Yearly, 2001-2014 & 2001-2014 & $500 \mathrm{~m}$ & LPDAAC \\
\hline $\begin{array}{l}\text { Growing season } \\
\text { length (GSL) }\end{array}$ & $\begin{array}{l}\text { MODIS Aqua, Terra; } \\
\text { MCD12Q2; } 5\end{array}$ & Yearly, 2001-2014 & 2001-2014 & $500 \mathrm{~m}$ & LPDAAC \\
\hline Burned area & MODIS Aqua, Terra; ABBA; 2 & Yearly, 2001-2015 & 2001-2015 & $500 \mathrm{~m}$ & Loboda et al. (2017) \\
\hline Marine chlorophyll (Chl) & $\begin{array}{l}\text { MODIS Aqua; } \\
\text { MO_chlor_a; } 2014.0\end{array}$ & Monthly, 2003-2017 & $\begin{array}{r}\text { 2003-2017, } \\
\text { Apr-Oct }\end{array}$ & $4 \mathrm{~km}$ & NASA OceanColor \\
\hline $\begin{array}{l}\text { Colored dissolved organic } \\
\text { material (CDOM) }\end{array}$ & $\begin{array}{l}\text { MODIS Aqua; } \\
\text { MO_IOP_adg_443_giop; NA }\end{array}$ & Monthly, 2003-2017 & $\begin{array}{r}\text { 2003-2017, } \\
\text { Apr-Oct }\end{array}$ & $4 \mathrm{~km}$ & NASA OceanColor \\
\hline $\begin{array}{l}\text { Sea surface temperature } \\
\text { (SST) }\end{array}$ & $\begin{array}{l}\text { MODIS Aqua; MO_SST4; } \\
2014.0\end{array}$ & Monthly, 2003-2017 & $\begin{array}{l}\text { 2003-2017, } \\
\text { Jan-Dec }\end{array}$ & $4 \mathrm{~km}$ & NASA OceanColor \\
\hline $\begin{array}{l}\text { Marine primary } \\
\text { productivity (PP) }\end{array}$ & MODIS Aqua; VGPM; NA & Monthly, 2003-2016 & $\begin{array}{r}\text { 2003-2016, } \\
\text { Apr-Oct }\end{array}$ & $9 \mathrm{~km}$ & O’Malley (2017) \\
\hline Sea ice extent & $\begin{array}{l}\text { Combined Passive Microwave } \\
\text { (SMMR and SSM/I-SSMIS); } 2\end{array}$ & Monthly, 1978-2016 & $\begin{array}{c}\text { 2003-2016, } \\
\text { Jan-Dec }\end{array}$ & $25 \mathrm{~km}$ & NSIDC \\
\hline
\end{tabular}

surface temperature biases due to cloud cover contamination (Westermann et al. 2011). Data quality flags, when available, have been applied to the data in this study to limit effects from cloud cover and snow, but no additional smoothing or model fitting was conducted.

The remote sensing data products were converted from their source format to a GeoTIFF, re-projected into the Lambert Azimuthal Equal Area projection, and clipped to the CAFF pan-Arctic extent. The terrestrial and combined MODIS products from LPDAAC were processed using the HDF-EOS to GeoTIFF Conversion Tool (HEG Tool; HEG 2017), and the Aqua MODIS products and non-MODIS products were processed using the Geospatial Data Abstraction Library (GDAL; GDAL 2017). MODIS MCD12Q2 products were distributed as tiles and were stitched together using ESRI's Mosaic to New Raster tool after re-projection.

The data used in this analysis, including the fully processed and clipped versions, have been archived at the Arctic Biodiversity Data Service (ABDS, https://www. abds.is/) under Land Cover Change. Additional geospatial data layers used in this analysis reside at this location as well as pan-Arctic headline indicator data, CBMP data, boundaries, and sensitive and protected areas data.
Remote sensing data were used to calculate average annual and seasonal time series over the 14- to 18-year observation periods. These analyses were performed at the pan-Arctic level as well as within defined analysis areas. In addition to the pan-Arctic extent, marine parameters were analyzed by high, low, and sub-Arctic areas and terrestrial parameters were analyzed by the five bioclimate subzones defined by the Circumpolar Arctic Vegetation Map, CAVM (CAVM Team 2003). Figure 1 shows the geospatial boundaries of the analysis areas.

Data were standardized to facilitate a uniform comparison between parameters and between the terrestrial and marine environments. For each variable, each data point was standardized by subtracting the variable's mean over its entire temporal span and dividing by the variable's standard deviation over the same temporal span. After standardization, all parameter datasets are unitless with a mean of zero and standard deviation of 1.

All statistical analyses were conducted in $\mathrm{R}$ ( $\mathrm{R}$ Core Team 2015). After aggregating data to the yearly level, annual trends were analyzed using ordinary least squares (OLS) regression and slope significance was determined using a two tailed $t$ test with a $p$ value threshold of 0.05 . The BFAST package in R (Breaks for Additive Seasonal 

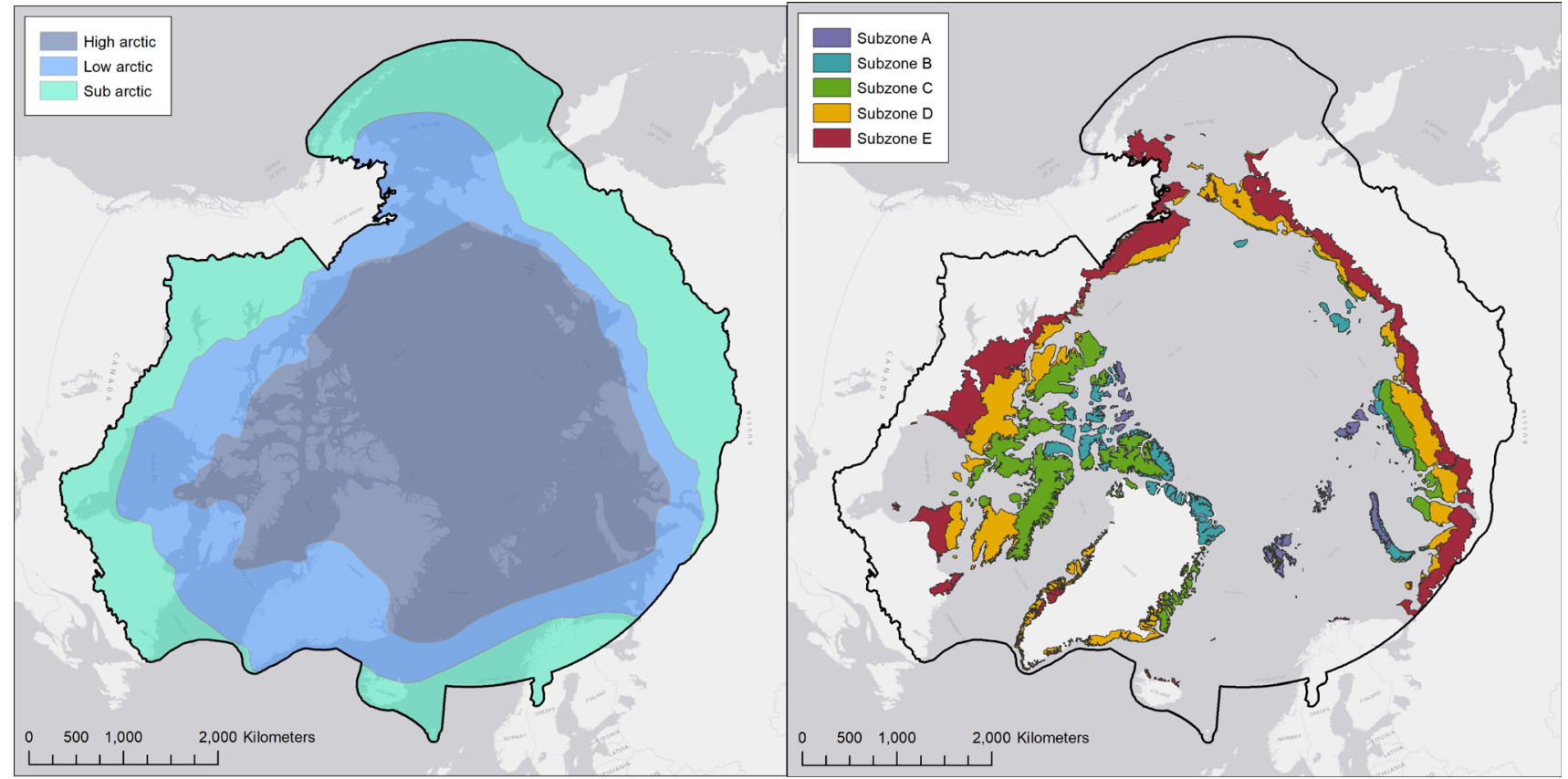

Fig. 1 In addition to the entire pan-Arctic extent, several geographic analysis areas were used to parse data and report findings, including high, low, and sub-Arctic (left) and the CAVM bioclimate zones (right)

and Trend; Verbesselt et al. 2010) was also used to identify long-term trends in the parameters and to identify breakpoints, if present, in the time series where monthly or 16-day seasonal data were available. This approach decomposes a time series into trend, seasonal, and remainder components and searches for significant changes or breakpoints in the trend or seasonal components. A minimum segment size of 3 years (representing approximately $20 \%$ of the data record as was used in Verbesselt et al. 2010) was set to avoid the detection of short-term anomalies. When significant breakpoints were identified, the slope and its significance were reported for each side of the change.

\section{RESULTS}

This study identified statistically significant temporal rates of change in many physical and ecological parameters, whether assessed across the pan-Arctic as a whole or analyzed by regions or subzones. Different rates of change as well as magnitude and directional shifts in trends were also detected. In terms of annual versus seasonal data, more statistically significant trends were identified in the seasonal data in both the terrestrial and marine parameters.

The power of parsing data by geospatial regions is shown in the average annual land surface temperature plots in Fig. 2. A clear separation of the data by bioclimate subzone is observed in Fig. 2a, which generally follows latitudinal trends. While subzones $\mathrm{A}, \mathrm{B}, \mathrm{D}$, and $\mathrm{E}$ all experienced significant increases in temperature across the observation period, the highest temperatures were seen in the southernmost zones (D and E). Standardizing the data more clearly shows how the rate of change of temperature varies across the regions (Fig. 2B). Subzone A exhibited the greatest increase (slope $=0.146$ ), followed by subzones $\mathrm{E}, \mathrm{B}$, and D (slopes $=0.124,0.11$, and 0.103 , respectively).

Monthly land surface temperature data also showed heterogeneous responses between CAVM subzones. For instance, subzone A exhibited significant increasing trends in January, February, March, April, September, October, and November $(p$ values $=0.031,0.028,0.002,0.04$, $0.026,0.002$, and 0.012 , respectively). Subzone E, the southernmost vegetation zone, also showed increasing trends, but only in the months April-June ( $p$ values $=0.016,0.01$, and 0.004, respectively). This indicates that while nearly all CAVM subzones exhibited significant rises in average land surface temperature over the 2001-2017 observation period, there was north-south variability in the seasonality of temperature change. The northernmost CAVM subzone experienced significant rising temperature trends in fall, winter, and spring, while the southernmost CAVM subzone showed a significant rising temperature trend in late spring to early summer.

The aggregated average annual pan-Arctic data showed statistically significant temporal trends in land surface temperature and NDVI $(p=0.04$ and $p<0.001$, respectively; Fig. 3). The standardized rate of change in NDVI 

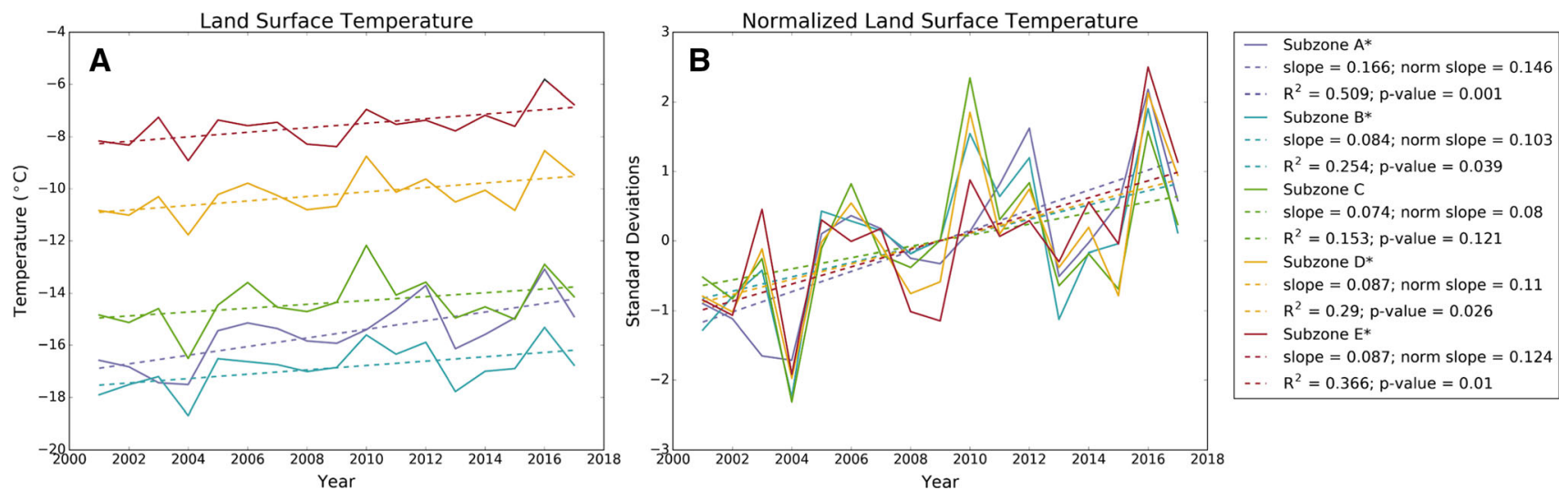

Fig. 2 Plots of land surface temperature by bioclimate CAVM subzones show a clear separation of temperature within the different zones. a The non-standardized data. Subzones A, B, D, \& E have statistically significant increasing trends as indicated by an asterisk in the legend ( $p$ values 0.001, 0.039, 0.026, and 0.010, respectively). Disregarding the absolute differences, the standardized plot (b) more clearly shows the common shifts in rates and directions of change as well as differences among subzones. CAVM subzone A, the northernmost zone, showed the greatest rate of overall increase in land surface temperature, followed by subzones $\mathrm{E}, \mathrm{B}$, and $\mathrm{D}$
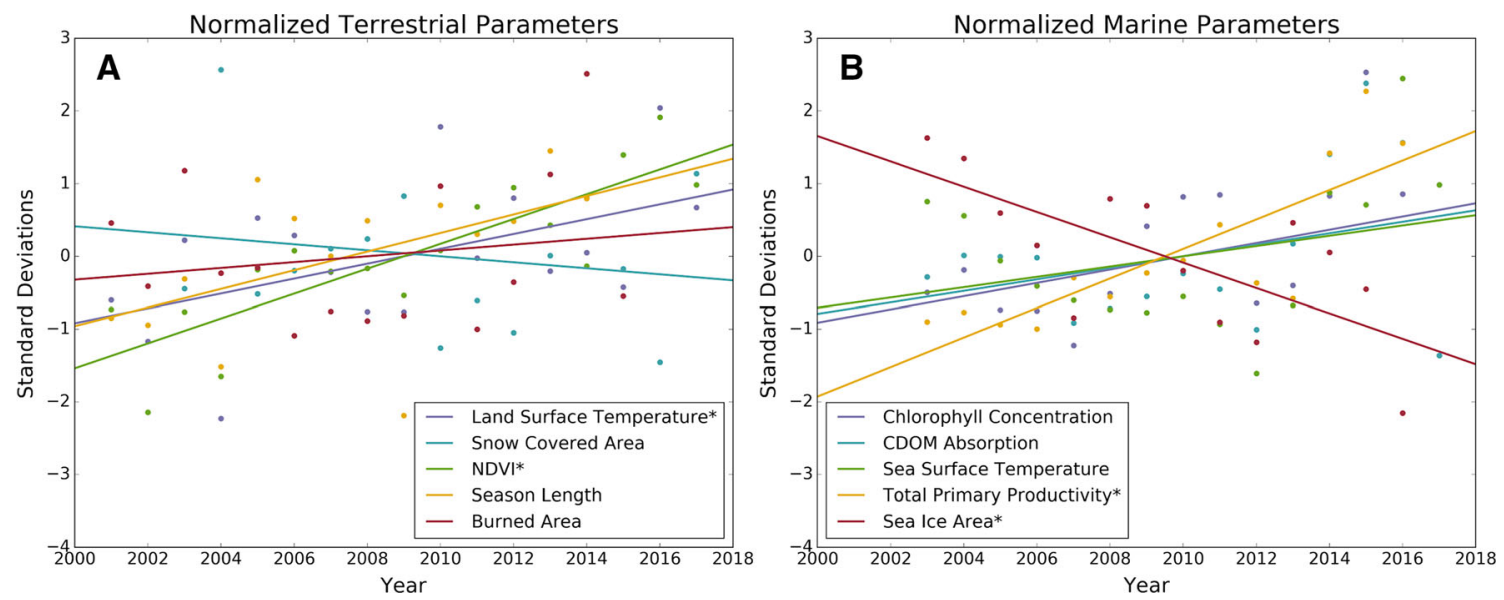

Fig. 3 Average annual standardized data have been plotted for the pan-Arctic to show rates of change among the different parameters and compare the terrestrial (a) with the marine (b) environments. Statistically significant trends are marked with an * in the legend. Detailed statistics for the trends are available in Table 2

was greater than that of temperature $(0.166$ and 0.099 , respectively). EVI was also assessed with similar results to NDVI in all analysis areas. The average annual data indicated that both land surface temperature and NDVI were significantly increasing in CAVM subzones A, B, D, and E ( $p$ values in Table 2 ). The BFAST analysis, by incorporating seasonal variability, showed similar results for the pan-Arctic and these subzones while also indicating a significantly increasing trend both parameters in CAVM subzone $\mathrm{C}$. This analysis also indicated a breakpoint in 2013 for CAVM subzones B and C such that the land surface temperature rate of increase became significantly higher.

In terms of terrestrial phenology, three different parameters were analyzed: greenup date, senescence date, and growing season length. No significant trends were observed in senescence date. Subzones C and E showed a statically significant decrease for the green up date, indicating that the growing season shifted to an earlier start date over time (changes of 4.5 and 4 days over 14 years, respectively). Related to this, subzones B and E showed a statistically significant increase in growing season length (with changes of 5 and 3.5 days, respectively). BFAST analysis was not applied to phenology data since there is only one value for each parameter each year (i.e., there is no monthly green up date).

No significant trends were observed in the average annual percent snow covered areas, though looking at time series for individual months did reveal significant trends. Significant declining trends were observed in subzones C 
Table 2 Summary rates of change for the standardized data and the associated $p$ values in parentheses. Statistically significant trends are bolded and marked with an *. Confidence intervals for the data are presented in the Electronic Supplementary Material S1

\begin{tabular}{|c|c|c|c|c|c|c|c|}
\hline Terrestrial & Land surface temp & Snow cover & NDVI & Green up & Senescence & Season length & Burned area \\
\hline Pan-Arctic & $0.099(0.041 *)$ & $-0.040(0.524)$ & $0.166(<0.001 *)$ & $-0.125(0.056)$ & $-0.062(0.368)$ & $0.123(0.059)$ & $0.039(0.537)$ \\
\hline Subzone A & $0.141(0.001 *)$ & $0.011(0.862)$ & $0.155(<0.001 *)$ & $-0.004(0.956)$ & $0.0409(0.559)$ & $0.079(0.247)$ & NA \\
\hline Subzone B & $0.100(0.039 *)$ & $-0.020(0.749)$ & $0.148(0.001 *)$ & $-0.099(0.142)$ & $-0.009(0.897)$ & $0.1336(0.038 *)$ & NA \\
\hline Subzone C & $0.077(0.121)$ & $-0.060(0.335)$ & $0.080(0.107)$ & $-0.135(0.036 *)$ & $-0.125(0.054)$ & $0.066(0.340)$ & NA \\
\hline Subzone D & $0.107(0.026 *)$ & $-0.081(0.184)$ & $0.143(0.001 *)$ & $-0.097(0.148)$ & $-0.063(0.364)$ & $0.104(0.119)$ & $0.002(0.971)$ \\
\hline Subzone E & $0.120(0.010 *)$ & $-0.045(0.475)$ & $0.156(<0.001 *)$ & $-0.129(0.047 *)$ & $-0.028(0.688)$ & $0.147(0.019 *)$ & $-0.060(0.335)$ \\
\hline Marine & Chlorophyll & \multicolumn{2}{|c|}{ CDOM } & Sea surface temp & \multicolumn{2}{|c|}{ Sea ice (2003-2017) } & Total PP \\
\hline Pan-Arctic & $0.088(0.146)$ & \multicolumn{2}{|c|}{$0.076(0.212)$} & $0.068(0.268)$ & \multicolumn{2}{|c|}{$-0.168(0.005 *)$} & $0.196(<0.001 *)$ \\
\hline High Arctic & $0.094(0.117)$ & \multicolumn{2}{|c|}{$0.078(0.200)$} & $0.103(0.085)$ & \multicolumn{2}{|c|}{$-0.172(0.004 *)$} & $0.174(0.003 *)$ \\
\hline Low Arctic & $0.093(0.124)$ & \multicolumn{2}{|c|}{$0.0728(0.236)$} & $0.087(0.152)$ & \multicolumn{2}{|c|}{$-0.026(0.710)$} & $0.152(0.015 *)$ \\
\hline Sub-Arctic & $0.044(0.479)$ & \multicolumn{2}{|c|}{$0.078(0.206)$} & $0.075(0.220)$ & \multicolumn{2}{|c|}{$0.080(0.241)$} & $0.093(0.169)$ \\
\hline
\end{tabular}

and $\mathrm{D}$ for the month of June ( $p$ value $=0.020$ and 0.028 ), subzone $\mathrm{E}$ for the month of July ( $p$ value $=0.013$ ), and subzones A and B for the month of October ( $p$ value $=0.005$ and 0.033 ). Observations of the seasonal data within the changepoint analysis revealed significant declining trend from 2000 to 2011 ( $p$ value $=0.019$ ) followed by a significant increasing trend from 2011 to 2014 in subzone $\mathrm{B}$ ( $p$ value $<0.001)$. No other significant seasonal trends were identified.

No trends were found in the measures of amount of average annual burned area across the pan-Arctic. Burned area polygons were not present in subzones $\mathrm{A}$ and $\mathrm{B}$. The burned area product is only available at a yearly time scale so the seasonal breakpoint analysis could not be performed.

By standardizing the data we can see that the terrestrial and marine environments have both experienced somewhat similar amounts of change, when expressed as standardized standard deviation from each variable's mean (Fig. 3). The change plots show the standardized parameters and their positive or negative rate of change. In the marine environment, two parameters, sea ice and primary productivity, showed significant change over the observation period. In the terrestrial environment, parameters are more closely grouped with NDVI and land surface temperature showing the greatest rate of change. Interestingly, the rates of change of NDVI and sea ice were approximately the same (0.166 and -0.168 , respectively). The detailed statistics for the rates of change and significance values are shown in Table 2.

Observations of the seasonal data reveal changes in the seasonal dynamics. Figure 4 shows the seasonal curves of the land surface temperature data over the two decadal time series. The BFAST statistical software identifies the line of best fit, incrementally, over the time series which may result in one or more lines of fit. Figure 4 shows changepoints in the land surface temperature data record for subzones $\mathrm{B}$ and $\mathrm{C}$. Both of these changepoint years occur in 2013 and indicate a magnitude shift from the 2001 to 2013 data record to the 2013 to 2017 record. That is to say, the warming trend accelerated during these time periods.

\section{DISCUSSION}

A large number of parameters show a statistically significant temporal trend over the almost two decade time series. This is of note in and of itself, but many of these statistically significant trends are also showing a magnitude or directional breakpoint within this limited temporal observation window.

Comparing many parameters simultaneously within the same methodological framework provides context and a frame of reference for observed change. For example, sea ice decline is frequently reported on in both the scientific and popular media, and the rate of change in sea ice extent is generally considered significant and alarming. Results from this study show that the rate of change in sea ice extent is comparable to total primary productivity, albeit in opposite directions. In the terrestrial environment, NDVI has similar rates of change to sea ice and primary productivity.

Study findings are temporally limited by the MODIS dataset in terms of number of years of observations. Many trends were marginally significant or have specific outlier years that affect the overall statistical significance. This is an indication that more changes may be occurring across the pan-Arctic than are being reported in this study and that more change may be on the horizon. Specifically, several of the marine parameters including primary productivity 


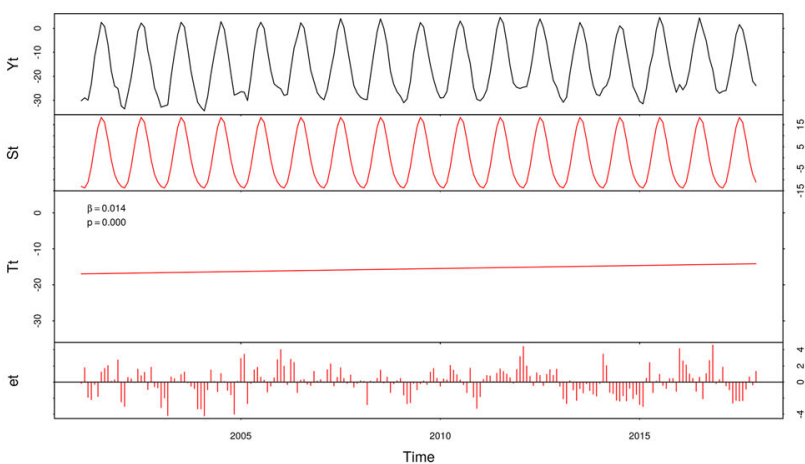

Subzone A

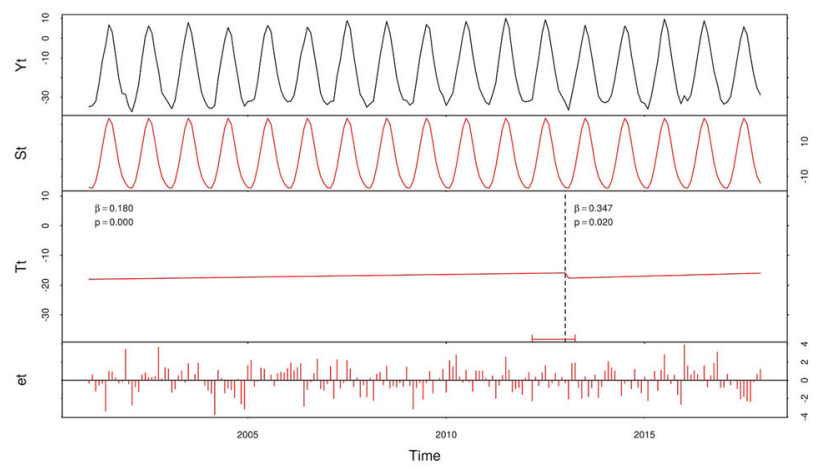

Subzone B

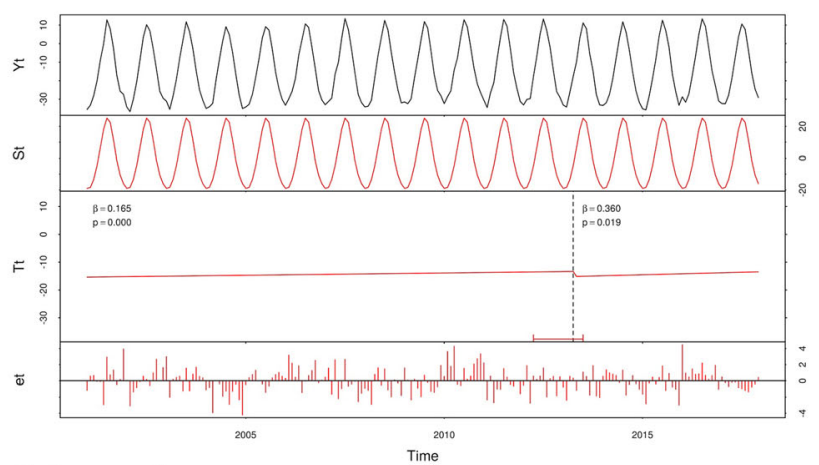

Subzone C

Fig. 4 Results from the BFAST changepoint analysis on the seasonal land surface temperature data show breaks in the trends in subzones B and $\mathrm{C}$ occurring in 2013 for both subzone. The trends for all subzones are statistically significant as indicated by the respective $p$ values printed in panel three of each subzone output. The output graphs show the fully plotted data in the top panel, followed by the seasonal trends. The third panel in each output shows the annual trend and any identified breaks in trend with associated error bars. The fourth panel shows the residual differences from the trend

and sea surface temperature show an uptick in measurements during the final two observations years (2016 and 2017). Given a few more years of data, this could be determined to represent a shift to a new normal or an anomaly in the data record. Regardless, more data are needed in order to develop a better sense of the temporal variability of these parameters.

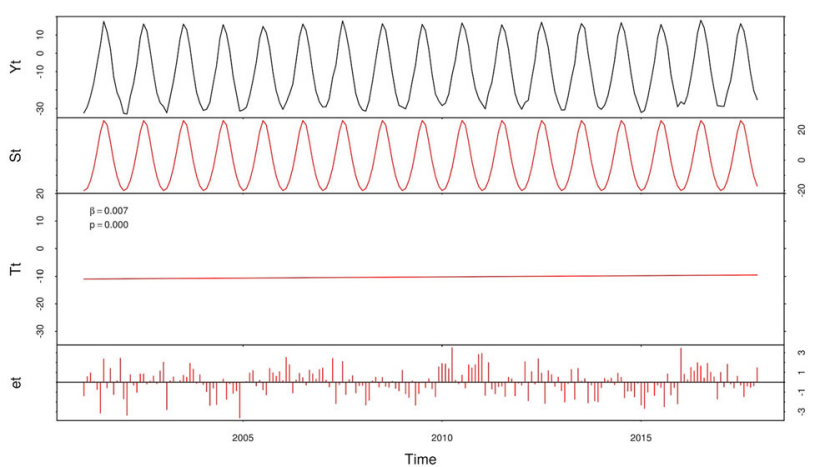

Subzone D

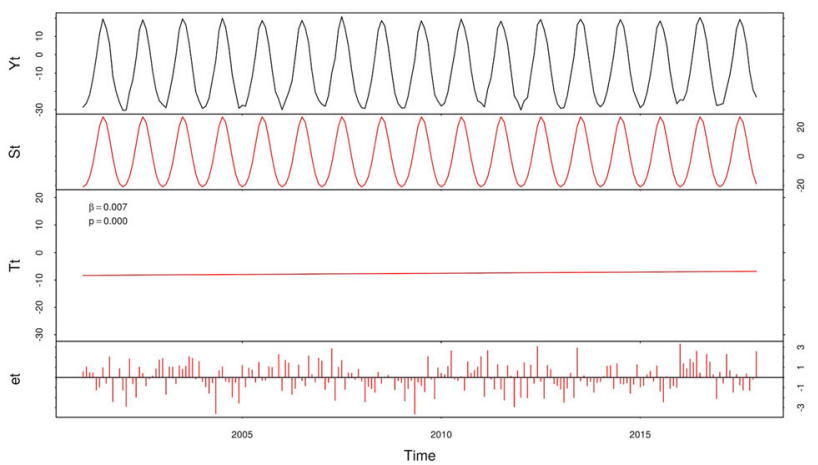

Subzone E

Fig. 4 continued

NDVI and EVI results are in agreement with other studies pointing to a "greening" trend across the panArctic (Jia et al. 2003; Goetz et al. 2005; Bhatt et al. 2010, 2013; Reichle et al. 2018). Most studies use the NASA GIMMS dataset based on AVHRR satellite data for NDVI comparison. This effort focuses on MODIS satellite data and data products, providing yet another data record for corroboration of "greening" in the Arctic.

The vegetation phenology results show that the greenup date is moving earlier by nearly six days and the growing season length is extending by approximately 4 days over the 2001-2014 observation period across the pan-Arctic. This is consistent to what others have reported in the Arctic with Zeng et al. 2011 reporting a earlier start of season by 4.7 days and a later end of season by 1.6 days for the period 2000-2010, for areas $\mathrm{N}$ of $60^{\circ}$ latitude, using MODIS NDVI data. These results are similar despite methodological differences in vegetation index computation, years of observations, and geographic region of analysis. The MODIS vegetation phenology product (MCD12Q2) used in this study is based on EVI data where many other studies of phenological trends use NDVI data (Zeng et al. 2011, 2013; Karami et al. 2017). In this study, we also found a greater year-to-year variability in the date of senescence than greenup, with results showing a somewhat cyclical trend. 
Table 3 Summary table showing the BFAST-derived trends and changepoints for parameters with seasonal data. + indicates a statistically significant increasing trend, -- indicates a decreasing trend, and empty cells indicate a non-significant trend. Grey cells indicate that a significant shift in the trend occurred in that year

\begin{tabular}{|c|c|c|c|c|c|c|c|c|c|c|c|c|c|c|c|c|c|c|}
\hline Marine & & 2001 & 2002 & 2003 & 2004 & 2005 & 2006 & 2007 & 2008 & 2009 & 2010 & 2011 & 2012 & 2013 & 2014 & 2015 & 2016 & 2017 \\
\hline Chlorophyll & Pan--Arctic & na & na & & & & & & & & -- & -- & -- & -- & & -- & -- & -- \\
\hline Chlorophyll & High Arctic & na & na & + & + & + & + & + & + & & -- & -- & -- & -- & & -- & -- & -- \\
\hline Chlorophyll & Low Arctic & na & na & + & + & + & + & + & + & + & + & + & + & + & + & + & + & + \\
\hline Chlorophyll & Sub Arctic & na & na & & & & & & & & & & & & & & & \\
\hline CDOM & Pan--Arctic & na & na & & & & & & & & & & + & + & & -- & -- & -- \\
\hline CDOM & High Arctic & na & na & + & + & + & + & + & + & + & + & + & + & + & & -- & -- & -- \\
\hline CDOM & Low Arctic & na & na & & & & & + & + & + & + & & + & + & & -- & -- & -- \\
\hline CDOM & Sub Arctic & na & na & & & & & & & & & & + & + & & $\overline{--}$ & -- & -- \\
\hline Sea Surface Temperature & Pan--Arctic & na & na & -- & -- & -- & -- & -- & -- & -- & -- & -- & -- & & + & + & + & + \\
\hline Sea Surface Temperature & High Arctic & na & na & & & & & & & & & & & & & & & \\
\hline Sea Surface Temperature & Low Arctic & na & na & -- & -- & -- & -- & -- & -- & -- & -- & -- & -- & -- & & & & \\
\hline Sea Surface Temperature & Sub Arctic & na & na & -- & -- & -- & -- & & & & & & & & & & & \\
\hline Sea Ice Area & Pan--Arctic & na & na & -- & -- & -- & -- & & -- & -- & -- & -- & & -- & -- & -- & -- & na \\
\hline Sea Ice Area & High Arctic & na & na & -- & -- & -- & -- & -- & & -- & -- & -- & & -- & -- & -- & -- & na \\
\hline Sea Ice Area & Low Arctic & na & na & + & + & + & + & + & + & + & & + & + & & -- & -- & -- & na \\
\hline Sea Ice Area & Sub Arctic & na & na & & & & & & & -- & -- & & & & & & & na \\
\hline Total Primary Productivity & Pan--Arctic & na & na & + & + & + & + & + & + & + & + & + & + & & & & & na \\
\hline Total Primary Productivity & High Arctic & na & na & + & + & + & + & + & + & + & + & + & + & + & + & + & + & na \\
\hline Total Primary Productivity & Low Arctic & na & na & & & & & & & & & & & & + & + & + & na \\
\hline Total Primary Productivity & Sub Arctic & na & na & -- & -- & -- & -- & -- & & & & & & & & & & na \\
\hline \multicolumn{19}{|l|}{ Terrestrial } \\
\hline Land Surface Temperature & Pan--Arctic & + & + & + & + & + & + & + & + & + & + & + & + & + & + & + & + & + \\
\hline Land Surface Temperature & Subzone A & + & + & + & + & + & + & + & + & + & + & + & + & + & + & + & + & + \\
\hline Land Surface Temperature & Subzone B & + & + & + & + & + & + & + & + & + & + & + & + & & + & + & + & + \\
\hline Land Surface Temperature & Subzone C & + & + & + & + & + & + & + & + & + & + & + & + & & + & + & + & + \\
\hline Land Surface Temperature & Subzone D & + & + & + & + & + & + & + & + & + & + & + & + & + & + & + & + & + \\
\hline Land Surface Temperature & Subzone $\mathrm{E}$ & + & + & + & + & + & + & + & + & + & + & + & + & + & + & + & + & + \\
\hline Percent Snow Cover & Pan--Arctic & na & na & & & & & & & & & & & & & & & \\
\hline Percent Snow Cover & Subzone A & na & na & & & & & & & & & & & & & & & \\
\hline Percent Snow Cover & Subzone B & na & na & -- & -- & -- & -- & -- & -- & -- & -- & & + & + & & & & \\
\hline Percent Snow Cover & Subzone C & na & na & & & & & & & & & & & & & & & \\
\hline Percent Snow Cover & Subzone D & na & na & & & & & & & & & & & & & & & \\
\hline Percent Snow Cover & Subzone E & na & na & & & & & & & & & & & & & & & \\
\hline NDVI & Pan--Arctic & + & + & + & + & + & + & + & + & + & + & + & + & + & + & + & + & + \\
\hline NDVI & Subzone A & + & + & + & + & + & + & + & + & + & + & + & + & + & + & + & + & + \\
\hline NDVI & Subzone B & + & + & + & + & + & + & + & + & + & + & + & + & + & + & + & + & + \\
\hline NDVI & Subzone C & + & + & + & + & + & + & + & + & + & + & + & + & + & + & + & + & + \\
\hline $\mathrm{NDVI}$ & Subzone D & + & + & + & + & + & + & + & + & + & + & + & + & + & + & + & + & + \\
\hline NDVI & Subzone E & + & + & + & + & + & + & + & + & + & + & + & + & + & + & + & + & + \\
\hline
\end{tabular}

In the marine environment, 2013/2014 appears to be a tipping point in which the directionality and/or trend significance of several different parameters changed. Table 3 shows the specific breakpoints and includes significant breaks for all marine parameters and across all Arctic zones. Of note are that the pan-Arctic sea surface temperature shifted from a significant decreasing trend to a significant increasing trend in 2013 and CDOM showed a shift from an increasing trend to a decreasing trend in 2014 in all zones.

The marine parameters are more variable than the terrestrial parameters in terms of magnitude and directional shifts and the number of breakpoints. The trends in the terrestrial parameters are essentially all unidirectional. Going forward, the feedback mechanisms and the relationships between the marine and terrestrial parameters need to be investigated.

It is important to recognize the potential issues associated with the remote sensing data products used in this analysis. In this study, we applied the MODIS quality flags, when available, to reduce effect from clouds and snow but data artifacts still remain. We generally included more pixels than other discipline-specific studies or studies from 
specific geographic locations due to unknown and variable weather and climate scenarios and data artifacts across all the parameters and across the entire pan-Arctic. Additional noise filtering in our dataset has been provided by averaging the data over large geographic regions. Data standardization also serves to further smooth noise. There are many excellent solutions in the literature to achieve a more accurate satellite data record by combining satellite inputs with ground observations, models, and mathematics, and these solutions should be employed when working with absolute data and trend analysis for specific parameters.

A goal of the MODIS data products is to continually improve the retrieval algorithms and to provide these updates to the user community through version updates. Over time these remote sensing products will improve in accuracy and precision with better documentation of known issues. Additionally, the scientific community will continue to evaluate these products through comparisons to ground observations and models.

The relatively short MODIS data record (14-17 points depending on parameter) also limits our ability to make decisive conclusions about trends in the annual mean. Because the OLS regression approach is sensitive to extreme values, even a single outlier in the dataset could result in the conclusion of a significant trend. Additionally, the OLS assumption of homogeneity can fail if there is a discontinuity or breakpoint in the data (Lanzante 1996) or as a result of seasonal variation (de Jong and de Bruin 2012). Aggregating the data to a yearly level can also potentially mask interesting shifts in seasonal variability. For instance, an increase in annual mean surface temperature could be due to increased temperatures across the entire year, or it could be that the summers are getting warmer while the winter temperatures remain steady. The BFAST approach, which extracts long-term and seasonal trends from the full, non-aggregated dataset, is able to account for seasonal variability in identifying trends while also identifying significant breakpoints in both long-term and seasonal trends (Verbesselt et al. 2010). BFAST has been used in numerous remote sensing time series analyses (de Jong et al. 2012; Lambert et al. 2013), and is likely a more effective tool for future investigation of Arctic trends and shifts. It is important to note, however, that the minimum segment size allowed between changepoints (a parameter within the BFAST tool) could result in biases due to climatological phenomena such as the North Atlantic oscillation (NAO), Arctic oscillation (AO), and the Atlantic multidecadal oscillation (AMO).

As stated, one of the objectives of this paper is to demonstrate the applicability of remote sensing as a multiparameter monitoring tool (meaningful to implementation of the CBMP). The use of MODIS based remote sensing as an observation tool is self-evident, although work remains to better understand uncertainty in the presented (and other) remote sensing-derived focal ecosystem states and changes. That is, how is measurement uncertainty impacting results and therefore how reliably can remote sensing tools, exceptional for observation, be used for monitoring? Individual results presented here and discussed above do provide a synoptic view of change in the Arctic and change by biologically meaningful reporting units (marine and CAVM bioclimate subzones), and corroborate past finding of change in the Arctic; however, the real power here is two-fold, understanding of the status of spatial and temporal trends across multiple parameters simultaneously, and serving as potential explanatory variables for in situ changes observed across the myriad CBMP focal ecosystem components.

\section{CONCLUSION}

MODIS is a powerful monitoring and analysis tool for the Arctic in terms of spatial coverage of the entire pan-Arctic on a daily timescale. The growing season in the Arctic is short and the temporal resolution afforded by MODIS is needed in order to capture phenological and seasonal changes occurring on a daily to weekly scale. Having daily data also provides the ability to account for cloud cover in the Arctic through composite images. The sea ice data provided by passive microwave in this study complement the electro-optical MODIS data products. Passive microwave data, which are not affected by cloud cover or solar illumination, provide valuable data during the winter months.

The analyses presented here should be updated every few years to provide a data stream useful for monitoring programs such as CBMP. This study, and many others, show significant change is occurring in the Arctic. We need to determine how resilient the Arctic is to these changes and where there may be certain thresholds, known also as "tipping points," beyond which an abrupt shift of physical or ecological states occur. The changepoint analysis presented here is a departure point for more detailed studies at different scales. In situ data from monitoring stations across the pan-Arctic may provide valuable calibration and validation data as well as provide early warning data to guide remote sensing-based parameter selection and algorithm development. Only with a combination of in situ data, remote sensing data, and an understanding of the processes occurring at different scales can we begin to understand change in the Arctic.

Acknowledgements Funding and support for this work has been provided by the Conservation of Arctic Flora and Fauna (CAFF) and the US Bureau of Land Management. We thank the Circumpolar 
Biodiversity Monitoring Program (CBMP) and the CAFF Secretariat for their support and guidance. We also thank John Payne and Matthew Whitley for their participation in earlier phases of this work, and we thank the anonymous reviewers for their constructive feedback.

\section{REFERENCES}

ACIA. 2004. Impacts of a warming arctic: Arctic climate impact assessment. ACIA Overview Report. Cambridge : Cambridge University Press.

Arrigo, K.R., G. van Dijken, and S. Pabi. 2008. Impact of shrinking Arctic ice cover on marine primary productivity. Geophysical Research Letters 35: L19603. https://doi.org/10.1029/2008GL035028.

Bhatt, U.S., D.A. Walker, M.K. Raynolds, J.C. Comison, H.E. Epstein, G. Jia, R. Gens, J.E. Pinzon, et al. 2010. Circumpolar arctic tundra vegetation change is linked to sea ice decline. Earth Interactions 14: 1-20. https://doi.org/10.1175/2010EI315.1.

Bhatt, U.S., D.A. Walker, M.K. Raynolds, P.A. Bieniek, H.E. Epstein, J.C. Comiso, J.E. Pinzon, C.J. Tucker, et al. 2013. Recent declines in warming and vegetation greening trends over panarctic tundra. Remote Sensing 5: 4229-4254. https://doi.org/10. 3390/rs5094229.

Bunn, A.G., S.J. Goetz, J.S. Kimball, and K. Zhang. 2007. Northern high-latitude ecosystems respond to climate change. Eos, Transactions American Geophysical Union 88: 333-335.

CAFF. 2017. State of the Arctic Marine Biodiversity Report. Conservation of Arctic Flora and Fauna International Secretariat, Akureyri, Iceland. 978-9935-431-63-9.

Carroll, M.L., J.R.G. Townshend, C.M. DiMiceli, T. Loboda, and R.A. Sohlberg. 2011. Shrinking lakes of the Arctic: Spatial relationships and trajectory of change. Geophysical Research Letters 38: L20406. https://doi.org/10.1029/2011GL049427.

CAVM Team. 2003. Circumpolar Arctic vegetation map. Scale 1:7 500 000. Conservation of Arctic Flora and Fauna (CAFF) Map No. 1. US Fish and Wildlife Service, Anchorage, Alaska, USA. Retrieved December 1, 2016, from http://www.geobotany. uaf.ed383-50-1292u/cavm/.

Comiso, J.C., C.L. Parkinson, R. Gersten, and L. Stock. 2008. Accelerated decline in the arctic sea ice cover. Geophysical Research Letters 35: L01703. https://doi.org/10.1029/2007GL031972.

de Jong, R., and S. de Bruin. 2012. Linear trends in seasonal vegetation time series and the modifiable temporal unit problem. Biogeosciences 9: 71-77. https://doi.org/10.5194/bg-9-71-2012.

de Jong, R., J. Verbesselt, M.E. Schaepman, and S. de Bruin. 2012. Trend changes in global greening and browning: Contribution of short-term trends to longer-term change. Global Change Biology 18: 642-655. https://doi.org/10.1111/j.1365-2486.2011.02578.x.

Dye, D.G., and C.J. Tucker. 2003. Seasonality and trends of snowcover, vegetation index, and temperature in northern Eurasia. Geophysical Research Letters 30: 1405. https://doi.org/10.1029/ 2002GL016384.

Epstein, H.E., M.K. Raynolds, D.A. Walker, U.S. Bhatt, C.J. Tucker, and J.E. Pinzon. 2012. Dynamics of aboveground phytomass of the circumpolar Arctic tundra during the past three decades. Environmental Research Letters 7: 015506. https://doi.org/10. 1088/1748-9326/7/1/015506.

Frey, K.E., G.W.K. Moore, L.W. Cooper, and J.M. Grebmeier. 2015. Divergent patterns of recent sea ice cover across the Bering, Chukchi, and Beaufort seas of the pacific arctic region. Oceanography 136: 32-49. https://doi.org/10.1016/j.pocean.2015.05.009.

GDAL. 2017. GDAL - Geospatial Data Abstraction Library: Version 2.2.3, Open Source Geospatial Foundation. Retrieved December 1, 2016, from http://gdal.osgeo.org.
Goetz, S.J., A.G. Bunn, G.J. Fiske, and R.A. Houghton. 2005. Satellite-observed photosynthetic trends across boreal North America associated with climate and fire disturbances. Proceedings of the National Academy of Sciences 102: 13521-13525. https://doi.org/10.1073/pnas.0506179102.

Hachem, S., M. Allard, and C. Duguay. 2009. Using the MODIS land surface temperature product for mapping permafrost: an application to Northern Quebec and Labrador. Canada. Permafrost and Periglacial Processes 20: 407-416. https://doi.org/10.1002/ ppp.672.

Hall, D.K., and G.A. Riggs. 2007. Accuracy assessment of the MODIS snow products. Hydrological Processes: An International Journal 21: 1534-1547. https://doi.org/10.1002/hyp.6715.

Hansen, J., R. Ruedy, J. Glascoe, and M. Sato. 1999. GISS analysis of surface temperature change. Journal of Geophysical Research 104: 30997-31022. https://doi.org/10.1029/1999JD900835.

HEG. 2017. HDF-EOS to GeoTIFF Conversion Tool (HEG), Version 2.14, Earth Observing System (EOS) Program, National Aeronautics and Space Administration. Retrieved December 1, 2016, from https://newsroom.gsfc.nasa.gov/sdptoolkit/HEG/ HEGHome.html.

Hill, V.J., P.A. Matrai, E. Olson, S. Suttles, M. Steele, L.A. Codispoti, and R.C. Zimmerman. 2012. Synthesis of integrated primary production in the Arctic Ocean: II. In situ and remotely sensed estimates. Oceanography 110: 107-125. https://doi.org/10.1016/ j.pocean.2012.11.005.

Hope, A.S., J.S. Kimball, and D.A. Stow. 1993. The relationship between tussock tundra spectral reflectance properties and biomass and vegetation composition. International Journal of Remote Sensing 14: 1861-1874. https://doi.org/10.1080/ 01431169308954008.

Huete, A., C. Justice, and W. van Leeuwen. 1999. MODIS vegetation index (MOD13). Algorithm theoretical basis document 3: 213.

Huete, A., K. Didan, T. Miura, E.P. Rodriguez, X. Gao, and L.G. Ferreira. 2002. Overview of the radiometric and biophysical performance of the MODIS vegetation indices. Remote Sensing of Environment 83: 195-213. https://doi.org/10.1016/S00344257(02)00096-2.

IPCC. 2018. Global warming of $1.5^{\circ} \mathrm{C}$. An IPCC Special Report on the impacts of global warming of $1.5^{\circ} \mathrm{C}$ above pre-industrial levels and related global greenhouse gas emission pathways. In The context of strengthening the global response to the threat of climate change, sustainable development, and efforts to eradicate poverty, ed. V. Masson-Delmotte, P. Zhai, H.-O. Pörtner, D. Roberts, J. Skea, P.R. Shukla, A. Pirani, W. Moufouma-Okia, et al., 32. Geneva: Intergovernmental Panel on Climate Change.

Jia, G.J., H.E. Epstein, and D.A. Walker. 2003. Greening of arctic Alaska, 1981-2001. Geophysical Research Letters 30: 2067. https://doi.org/10.1029/2003GL018268.

Jia, G.J., H.E. Epstein, and D.A. Walker. 2009. Vegetation greening in the Canadian Arctic related to decadal warming. Journal of Environmental Monitoring 11: 2231-2238.

Karami, M., B.U. Hansen, A. Westergaard-Nielsen, J. Abermann, M. Lund, N.M. Schmidt, and B. Elberling. 2017. Vegetation phenology gradients along the west and east coasts of Greenland from 2001 to 2015. Ambio 46: 94-105. https://doi.org/10.1007/ s13280-016-0866-6.

Kaufman, D.S., D.P. Schneider, N.P. McKay, C.M. Ammann, R.S. Bradley, K.R. Briffa, G.H. Miller, B.L. Otto-Bliesner, et al. 2009. Recent warming reverses long-term arctic cooling. Science 325: 1236-1239. https://doi.org/10.1126/science.1173983.

Laidler, G.J., P.M. Treitz, and D.M. Atkinson. 2007. Remote sensing of arctic vegetation: Relations between the NDVI spatial resolution and vegetation cover on Boothia Peninsula. Nunavut. Arctic 61: 1-13. 
Lambert, J., C. Drenou, J.P. Denux, G. Balent, and V. Cheret. 2013. Monitoring forest decline through remote sensing time series analysis. GIScience \& Remote Sensing 50: 437-457. https://doi. org/10.1080/15481603.2013.820070.

Lanzante, J.R. 1996. Resistant, robust and non-parametric techniques for the analysis of climate data: Theory and examples, including applications to historical radiosonde station data. International Journal of Climatology: A Journal of the Royal Meteorological Society 16: 1197-1226. https://doi.org/10.1002/(SICI)10970088(199611)16:11\%3c1197:AID-JOC89\%3e3.0.CO;2-L.

Loboda, T.V., J.V. Hall, A.H. Hall, and V.S. Shevade. 2017. ABoVE: Cumulative Annual Burned Area, Circumpolar High Northern Latitudes, 2001-2015. ORNL DAAC, Oak Ridge, Tennessee, USA. Retrieved December 1, 2016, from https://doi.org/10.3334/ ORNLDAAC/1526.

McDonald, K.C., J.S. Kimball, E. Njoku, R. Zimmerman, and M. Zhao. 2004. Variability in springtime thaw in the terrestrial high latitudes: Monitoring a major control on the biospheric assimilation of atmospheric $\mathrm{CO}_{2}$ with spaceborne microwave remote sensing. Earth Interactions 8: 1-23. https://doi.org/10.1175/ 1087-3562(2004)8\%3c1:VISTIT\%3e2.0.CO;2.

Meltofte, H. (ed.). 2013. Arctic Biodiversity Assessment. Status and trends in Arctic biodiversity. Akureyri: Conservation of Arctic Flora and Fauna.

O'Malley, R. 2017. Ocean productivity. Retrieved December 1, 2018, from http://science.oregonstate.edu/ocean.productivity/index.php.

Park, T., S. Ganguly, H. Tommervik, E.S. Euskirchen, K. Hogda, S.R. Karlsen, V. Brovkin, R.R. Nemani, et al. 2016. Changes in growing season duration and productivity of northern vegetation inferred from long-term remote sensing data. Environmental Research Letters. https://doi.org/10.1088/1748-9326/11/8/084001.

Parkinson, C.L., D.J. Cavalieri, P. Gloersen, H.J. Zwally, and J.C. Comiso. 1999. Arctic sea ice extents, areas, and trends, 1978-1996. Journal of Geophysical Research 104: 20837-20856. https://doi. org/10.1029/1999JC900082.

R Core Team. 2015. R: A language and environment for statistical computing. R Foundation for Statistical Computing, Vienna, Austria. Retrieved December 1, 2016, from https://www.Rproject.org/.

Reichle, L.M., H.E. Epstein, U.S. Bhatt, M.K. Raynolds, and D.A. Walker. 2018. Spatial heterogeneity of the temporal dynamics of Arctic tundra vegetation. Geophysical Research Letters 45: 9206-9215. https://doi.org/10.1029/2018GL078820.

Riggs, G.A., and D.K. Hall. 2016. MODIS Snow Products Collection 6 User Guide. https://nsidc.org/sites/nsidc.org/files/files/MODISsnow-user-guide-C6.pdf.

Riordan, B., D. Verbyla, and A.D. McGuire. 2006. Shrinking ponds in subarctic Alaska based on 1950-2002 remotely sensed images. Journal of Geophysical Research 111: G04002. https://doi.org/ 10.1029/2005JG000150.

Smith, L.C., Y. Sheng, G.M. MacDonald, and L.D. Hinzman. 2005. Disappearing arctic lakes. Science 308: 1429. https://doi.org/10. 1126/science.1108142.

Stow, D.A., A.S. Hope, and T.H. George. 1993. Reflectance characteristics of arctic tundra vegetation from airborne radiometry. International Journal of Remote Sensing 14: 1239-1244. https://doi.org/10.1080/01431169308904408.

Stow, D.A., A. Hope, D. McGuire, D. Verbyla, J. Gamon, F. Huemmrich, S. Houston, C. Racine, et al. 2004. Remote sensing of vegetation and land-cover change in arctic tundra ecosystems. Remote Sensing of Environment 89: 281-308. https://doi.org/10. 1016/j.rse.2003.10.018.

Stroeve, J., and W. Meier. 2017. Sea ice trends and climatologies from SMMR and SSM/I-SSMIS, Version 2. ESMR-SMMR-SSM/ I-SSMIS-Merged Sea Ice Extent. Boulder: NASA National Snow and Ice Data Center Distributed Active Archive Center.
Retrieved December 1, 2016, from https://doi.org/10.5067/ EYICLBOAAJOU.

Stroeve, J., and D. Notz. 2018. Changing state of Arctic sea ice across all seasons. Environmental Research Letters 13: 103001.

Verbesselt, J., R. Hyndman, A. Zeileis, and D. Culvenor. 2010. Phenological change detection while accounting for abrupt and gradual trends in satellite image time series. Remote Sensing of Environment 114: 2970-2980. https://doi.org/10.1016/j.rse.2010. 08.003 .

Watts, J.D., J.S. Kimball, L.A. Jones, R. Schroeder, and K.C. McDonald. 2012. Satellite microwave remote sensing of contrasting surface water inundation changes within the arcticboreal region. Remote Sensing of Environment 127: 223-236. https://doi.org/10.1016/j.rse.2012.09.003.

Westermann, S., M. Langer, and J. Boike. 2011. Systematic bias of average winter-time land surface temperatures inferred from MODIS at a site on Svalbard. Norway. Remote Sensing of Environment 118: 162-167. https://doi.org/10.1016/j.rse.2011.10.025.

Zeng, H., G. Jia, and H. Epstein. 2011. Recent changes in phenology over the northern high latitudes detected from multi-satellite data. Environmental Research Letters 6: 045508. https://doi.org/ 10.1088/1748-9326/6/4/045508.

Zeng, H., G. Jia, and B.C. Forbes. 2013. Shifts in Arctic phenology in response to climate and anthropogenic factors as detected from multiple satellite time series. Environmental Research Letters 8: 035036. https://doi.org/10.1088/1748-9326/8/3/035036.

Publisher's Note Springer Nature remains neutral with regard to jurisdictional claims in published maps and institutional affiliations.

\section{AUTHOR BIOGRAPHIES}

Liza K. Jenkins $(\bowtie)$ is Research Scientist at the Michigan Tech Research Institute at Michigan Technological University.

Address: Michigan Tech Research Institute (MTRI), Michigan Technological University, 3600 Green Court, Suite 100, Ann Arbor, MI, USA.

Address: School for Environment and Sustainability, University of Michigan, 440 Church Street, Ann Arbor, MI, USA.

e-mail: lliverse@mtu.edu

Tom Barry is Executive Secretary of the Conservation of Arctic Flora and Fauna (CAFF), Arctic Council Working Group.

Address: Conservation of Arctic Flora and Fauna (CAFF), Borgir, Nordurslod, 600 Akureyri, Iceland.

Address: University of Iceland, Environment and Natural Resources, Haskolatorg Sæmundargata 4, 101 Reykjavík, Iceland.

e-mail: tom@caff.is

Karl R. Bosse is Research Scientist at the Michigan Tech Research Institute at Michigan Technological University.

Address: Michigan Tech Research Institute (MTRI), Michigan Technological University, 3600 Green Court, Suite 100, Ann Arbor, MI, USA.

e-mail: krbosse@mtu.edu

William S. Currie is Professor at the School for Environment and Sustainability (SEAS) at the University of Michigan.

Address: School for Environment and Sustainability, University of Michigan, 440 Church Street, Ann Arbor, MI, USA.

e-mail:wcurrie@umich.edu

Tom Christensen is a Professor at Aarhus University. Address: Aarhus University, Frederiksborgvej 399, 4000 Roskilde, Denmark.

e-mail: toch@bios.au.dk 
Sara Longan is the Executive Director of the North Slope Science Initiative.

Address: North Slope Science Initiative (NSSI), 222 West Seventh Avenue \#13, Anchorage, AK 99513, USA.

Address: Alaska Department of Natural Resources, 555 West 7th Ave, Anchorage, AK 99513, USA.

e-mail: Sara.longan@alaska.gov

Robert A. Shuchman is Co-Director at the Michigan Tech Research Institute (MTRI) at Michigan Technological University.

Address: Michigan Tech Research Institute (MTRI), Michigan

Technological University, 3600 Green Court, Suite 100, Ann Arbor, MI, USA.

e-mail: shuchman@mtu.edu
Danielle Tanzer is a Research Assistant at the Michigan Tech Research Institute (MTRI) at Michigan Technological University. Address: Michigan Tech Research Institute (MTRI), Michigan Technological University, 3600 Green Court, Suite 100, Ann Arbor, MI, USA.

e-mail:dntanzer@mtu.edu

Jason J. Taylor is Regional Chief of Natural Resources at the National Park Service Alaska Region.

Address: National Park Service, 240 West 5th Avenue, Anchorage, AK 99501, USA.

e-mail: jason_j_taylor@nps.gov 
Appendix S1. Presented here are the 95\% confidence intervals for the rates of change for the standardized data.

\begin{tabular}{|c|c|c|c|c|c|c|c|}
\hline & $\begin{array}{l}\text { Land } \\
\text { Surface } \\
\text { Temp }\end{array}$ & $\begin{array}{l}\text { Snow } \\
\text { Cover }\end{array}$ & NDVI & $\begin{array}{l}\text { Green } \\
\text { Up }\end{array}$ & Senescence & $\begin{array}{l}\text { Season } \\
\text { Length }\end{array}$ & $\begin{array}{l}\text { Burned } \\
\text { Area }\end{array}$ \\
\hline Pan-Arctic & $\begin{array}{l}(0.005 \\
0.194)\end{array}$ & $\begin{array}{l}(-0.172, \\
0.092)\end{array}$ & $\begin{array}{l}(0.106 \\
0.225)\end{array}$ & $\begin{array}{l}(-0.253, \\
0.004)\end{array}$ & $\begin{array}{l}(-0.207, \\
0.083)\end{array}$ & $\begin{array}{l}(-0.005 \\
0.252)\end{array}$ & $\begin{array}{l}(-0.093, \\
0.171)\end{array}$ \\
\hline Subzone A & $\begin{array}{l}(0.065 \\
0.218)\end{array}$ & $\begin{array}{l}(-0.123, \\
0.145)\end{array}$ & $\begin{array}{l}(0.087 \\
0.223)\end{array}$ & $\begin{array}{l}(-0.154, \\
0.146)\end{array}$ & $\begin{array}{l}(-0.107, \\
0.189)\end{array}$ & $\begin{array}{l}(-0.063, \\
0.221)\end{array}$ & NA \\
\hline Subzone B & $\begin{array}{l}(0.006 \\
0.194)\end{array}$ & $\begin{array}{l}(-0.154, \\
0.113)\end{array}$ & $\begin{array}{l}(0.076 \\
0.220)\end{array}$ & $\begin{array}{l}(-0.236 \\
0.038)\end{array}$ & $\begin{array}{l}(-0.159, \\
0.141)\end{array}$ & $\begin{array}{l}(0.009 \\
0.258)\end{array}$ & NA \\
\hline Subzone C & $\begin{array}{l}(-0.023, \\
0.178)\end{array}$ & $\begin{array}{l}(-0.189, \\
0.069)\end{array}$ & $\begin{array}{l}(-0.020 \\
0.180)\end{array}$ & $\begin{array}{l}(-0.259 \\
-0.010)\end{array}$ & $\begin{array}{l}(-0.253, \\
0.003)\end{array}$ & $\begin{array}{l}(-0.079, \\
0.210)\end{array}$ & NA \\
\hline Subzone D & $\begin{array}{l}(0.015 \\
0.198)\end{array}$ & $\begin{array}{l}(-0.206, \\
0.044)\end{array}$ & $\begin{array}{l}(0.068 \\
0.219)\end{array}$ & $\begin{array}{l}(-0.235 \\
0.040)\end{array}$ & $\begin{array}{l}(-0.208, \\
0.082)\end{array}$ & $\begin{array}{l}(-0.031, \\
0.240)\end{array}$ & $\begin{array}{l}(-0.132, \\
0.136)\end{array}$ \\
\hline Subzone E & $\begin{array}{l}(0.033, \\
0.207)\end{array}$ & $\begin{array}{l}(-0.176, \\
0.087)\end{array}$ & $\begin{array}{l}(0.089 \\
0.223)\end{array}$ & $\begin{array}{l}(-0.255 \\
-0.002)\end{array}$ & $\begin{array}{l}(-0.177, \\
0.121)\end{array}$ & $\begin{array}{l}(0.029 \\
0.266)\end{array}$ & $\begin{array}{l}(-0.189, \\
0.069)\end{array}$ \\
\hline & Chlorophyll & CDOM & $\begin{array}{l}\text { Sea } \\
\text { Surface } \\
\text { Temp }\end{array}$ & $\begin{array}{l}\text { Sea lce } \\
(2003- \\
2017)\end{array}$ & $\begin{array}{l}\text { Total } \\
\text { Primary } \\
\text { Productivity }\end{array}$ & & \\
\hline Pan-Arctic & $\begin{array}{l}(-0.035, \\
0.211)\end{array}$ & $\begin{array}{l}(-0.045 \\
0.202)\end{array}$ & $\begin{array}{l}(-0.059, \\
0.196)\end{array}$ & $\begin{array}{l}(-0.275 \\
-0.062)\end{array}$ & $\begin{array}{l}(0.109 \\
0.282)\end{array}$ & & \\
\hline High Arctic & $\begin{array}{l}(-0.027, \\
0.216)\end{array}$ & $\begin{array}{l}(-0.047, \\
0.204)\end{array}$ & $\begin{array}{l}(-0.016, \\
0.222)\end{array}$ & $\begin{array}{l}(-0.277, \\
-0.068)\end{array}$ & $\begin{array}{l}(0.071 \\
0.277)\end{array}$ & & \\
\hline Low Arctic & $\begin{array}{l}(-0.029 \\
0.215)\end{array}$ & $\begin{array}{l}(-0.054, \\
0.199)\end{array}$ & $\begin{array}{l}(-0.037, \\
0.210)\end{array}$ & $\begin{array}{l}(-0.176, \\
0.123)\end{array}$ & $\begin{array}{l}(0.035 \\
0.268)\end{array}$ & & \\
\hline Sub Arctic & $\begin{array}{l}(-0.087 \\
0.176)\end{array}$ & $\begin{array}{l}(-0.048, \\
0.203)\end{array}$ & $\begin{array}{l}(-0.051, \\
0.201)\end{array}$ & $\begin{array}{l}(-0.062, \\
0.222)\end{array}$ & $\begin{array}{l}(-0.045, \\
0.232)\end{array}$ & & \\
\hline
\end{tabular}

